\title{
Current Concepts of Surface Topography of Implants: A Review
}

\author{
Raksha Potdar $^{1}$ Amitha Ramesh ${ }^{1}$ \\ ${ }^{1}$ Department of Periodontics, AB Shetty Memorial Institute of Dental \\ Sciences, Mangalore, Karnataka, India \\ J Health Allied Sci ${ }^{\mathrm{NU}}$ 2022;12:208-211. \\ Address for correspondence Raksha Potdar, Department of \\ Periodontics, AB Shetty Memorial Institute of Dental Sciences, \\ Mangalore 515017, Karnataka, India \\ (e-mail: raksha.potdar@gmail.com).
}
Abstract
Keywords
- implants
- osseointegration
- surface topography

Both the rate of osseointegration and its extent depend upon the characteristics of the implant surface. ${ }^{1-5}$ Depending on the surface of the implant determination of implant-bone contact area, the rate of bone formation around the implant can be done. ${ }^{6}$ Hence, the implant surface plays an important part in multiple ways in the osseointegration process.

\section{Introduction}

The implant design factor that affects the rate as well as the extent of osseointegration is implant surface characteristics. ${ }^{1-5}$ The process of osseointegration is now well described both histologically and at the cellular level. The adhesion of a fibrin blood clot and the population of the implant surface by blood-derived cells and mesenchymal stem cells is orchestrated in a manner that results in osteoid formation and its subsequent mineralization. ${ }^{7-9}$

A seamless progression of changing cell populations and elaboration and modification of the tissue/implant interface eventually results in bone formation in direct contact with the implant surface. Precisely how much of the implant surface directly contacts the bone, how rapidly this bone accrual occurs, and the mechanical nature of the bone/implant connection is influenced by the nature of the implant surface itself. ${ }^{10}$

The characteristics of the implant surface are implicated in this complex process of osseointegration in several different ways.

\section{Surface Roughness of Titanium Implants}

Parameters such as implant surface topography and shape influence the surgical technique used and are important for good clinical outcomes and the success of implants. ${ }^{10}$
Two types of responses are seen once the implant comes in contact with the surrounding tissues.

1. Fibrous soft tissue capsule formation around the implant: Ideal biomechanical fixation cannot be obtained with the formation of this capsule, it can lead to implant failure.

2. Direct bone-implant contact without a connective tissue layer hindrance (osseointegration): Osseointegrated implants show a high success rate. This osseointegration depends on several other factors such as surface characteristics and the composition of the implants.

Nano, micro, and macro roughness are three types of implant surfaces topographies.

1. The macro level is directly related to implant design, with implant threads and surface treatments resulting in surface roughness of more than $10 \mathrm{~m}$. This type of implant surface results in mechanical interlocking between the implant and adjacent bone. Disadvantages of a macroporous surface are high chances of peri-implantitis and ion leakage. ${ }^{11}$

2. Moderate roughness $(1-2 \mu \mathrm{m})$ : It is defined as surface roughness in the range of 1 to $10 \mathrm{~m}$. The maximum interlocking in between the implant and bone is found in these implants. ${ }^{12-15}$
DOI https://doi.org/ $10.1055 / \mathrm{s}-0041-1736284$ ISSN 2582-4287. (c) 2021. Nitte (Deemed to be University). All rights reserved. This is an open access article published by Thieme under the terms of the Creative Commons Attribution-NonDerivative-NonCommercial-License, permitting copying and reproduction so long as the original work is given appropriate credit. Contents may not be used for commercial purposes, or adapted, remixed, transformed or built upon. (https://creativecommons.org/ licenses/by-nc-nd/4.0/)

Thieme Medical and Scientific Publishers Pvt. Ltd., A-12, 2nd Floor, Sector 2, Noida-201301 UP, India 
According to a study by Hansson et al, the ideal surface should have hemispherical pits $\sim 1.5 \mathrm{~m}$ in depth and $4 \mathrm{~m}$ in diameter. $^{16}$ In cases of low volume or poor quality of surrounding bone, rough surface implants should be used; in such conditions, high levels of bone to implant contact will allow for higher loading. Similarly, short implants with a rough surface are used in cases with short ridges, the results obtained were better than those compared with smooth surface implants. ${ }^{17,18}$

These studies have indicated that implants with rough surfaces have better interaction with the bone as compared with implants with smooth surfaces. ${ }^{13,19}$ However, no clinical evidence could be found by the Cochrane collaboration that demonstrated a particular surface treatment to be superior to the other. ${ }^{20}$

Surface characteristics in the nanometer range show increased osteoblast accumulation and protein adsorption, which promote osseointegration. ${ }^{21}$ Numerous techniques can be used for surface roughening of implants. These are described below.

\section{Titanium Plasma-Spraying}

Rough implants are produced using the titanium plasmaspraying (TPS) method (- Fig. 1).

This surface treatment causes an increase in the tensile strength at the bone to implant interface. ${ }^{14}$

Limitations: Leached-out titanium particles have sometimes been found in the bone adjacent to these implants. ${ }^{22}$ Metal ions released from implants may be the product of dissolution, fretting, and wear, and maybe a source of concern due to their potentially harmful local and systemic carcinogenic effects. ${ }^{23}$

\section{Grit Blasting}

Grit blasting is blasting the implant surface with hardened ceramic particles such as alumina, calcium phosphate particles, and titanium oxide. The particles pass from a nozzle at a high velocity under compressed air. Alumina $\left(\mathrm{Al}_{2} \mathrm{O}_{3}\right)$ is most

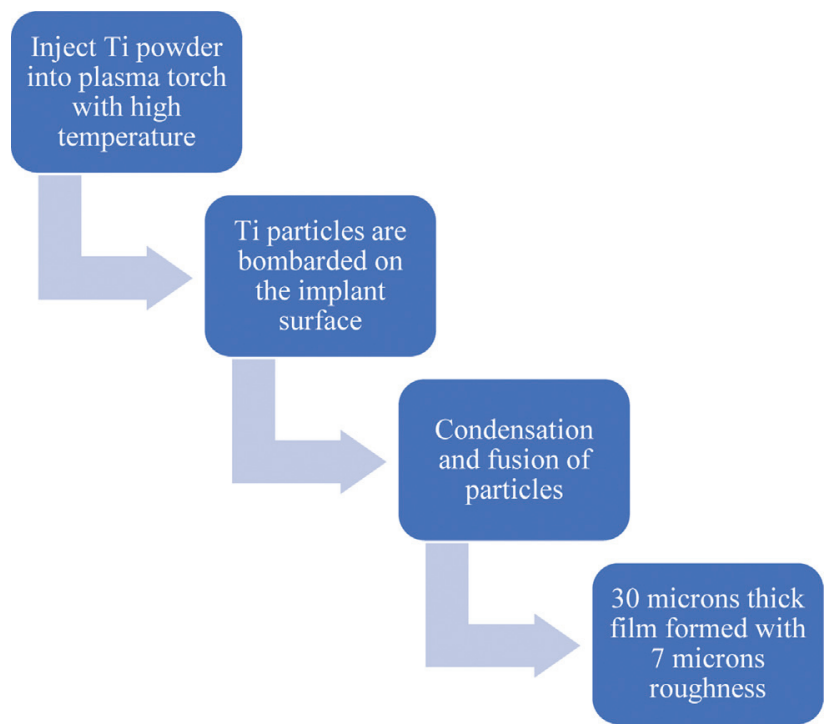

Fig. 1 Titanium plasma-spraying (TPS) method. commonly used and provides a surface roughness that depends on the size of the particles.

A disadvantage of blasting is that the particles stick onto the surface of the implant and may not be removed after acid passivation, ultrasonic cleaning, or sterilization. These particles may invade the adjacent tissues and hinder the process of osseointegration and decrease the corrosion resistance of titanium. $^{24}$

Titanium oxide can be used for surface treatment of titanium implants, an average size of $25 \mathrm{~m}$ (range: 1-2 $\mathrm{m}$ ) of the rough surface is formed. Studies have shown increased bone to implant contact in TiO-blasted implants as compared with machined surfaces. ${ }^{25}$ Titanium dental implants roughening can also be done using calcium phosphates such as hydroxyapatite, $\beta$-tricalcium phosphate, and mixtures.

Advantages: Particles are resorbable, which leads to a clean, textured, pure titanium surface. Studies have shown lesser bone-to-implant contact of these surfaces as compared with machined surfaces. ${ }^{26,27}$ and equal when compared with other blasted surfaces. ${ }^{28}$

\section{Acid Etching}

The implant surface can be processed using strong acids such as $\mathrm{HCl}, \mathrm{H}_{2} \mathrm{SO}_{4}, \mathrm{HNO}_{3}$, and $\mathrm{HF}$. These acid-etching procedures make micro pits on the surface, 0.5 to $2 \mathrm{~m}$ in diameter in size. ${ }^{29,30}$ Acid etching of implant surfaces helps in osseointegration (-Fig. 2).

These surfaces are shown to increase the osteoconductive process that results in bone formation on the implant surface. $^{31}$

Titanium dental implants can also be treated using fluoride solutions. Soluble $\mathrm{TiF}_{4}$ species are formed when titanium reacts with fluoride; a microrough surface is formed. This process provides double benefits as microroughness and incorporation of fluoride ions into the implant surface is achieved. Both these characteristics help in osseointegration. ${ }^{32,33}$ This procedure may further improve osseointegration by making the implant surface bioactive.

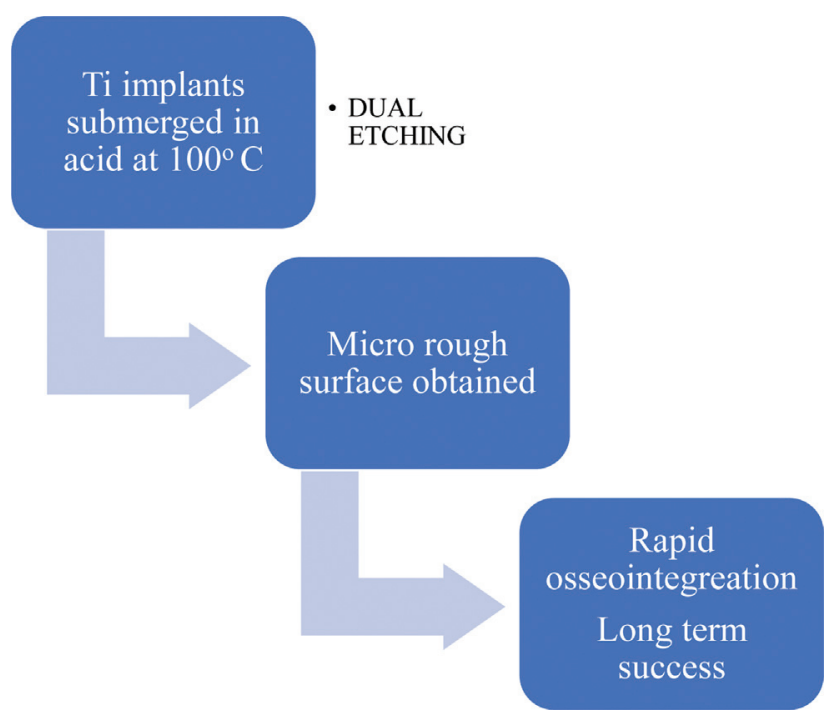

Fig. 2 Acid etching of implant surfaces. 
Various studies have indicated that implants treated by dual acid etching surface modification show a specific topography that enables them to attach to the fibrin scaffold as well as promote the adhesion of osteogenic cells, which enhances bone apposition. ${ }^{34,35}$ Recent improvements in acid-etching methods have been shown to increase cell adhesion and bone neoformation. High-temperature acidetching produces a homogeneous microporous surface with higher bone-to-implant contact than TPS surfaces in experimental studies. $^{36,37}$

However, treatment of titanium using chemicals might create microcracks that reduce its fatigue resistance and mechanical properties. ${ }^{38}$

\section{Anodization}

Micro- or nano-porous surfaces may be produced by potentiostatic or galvanostatic anodization of titanium in strong acids $\left(\mathrm{H}_{2} \mathrm{SO}_{4}, \mathrm{H}_{3} \mathrm{PO}_{4}, \mathrm{HNO}_{3}, \mathrm{HF}\right)$ at a high current density $\left(200 \mathrm{~A} / \mathrm{m}^{2}\right)$ or potential $(100 \mathrm{~V})$. Modifications in the microstructure and the crystallinity of the titanium oxide layer are created by anodization. ${ }^{39}$ The anodization is a complex process that depends on various parameters including current density, the concentration of acids, electrolyte composition, and electrolyte temperature. Anodized surfaces result in a strong reinforcement of the bone response with higher values for biomechanical and histomorphometric tests in comparison to machined surfaces. ${ }^{40,41}$ A higher clinical success rate was observed for the anodized titanium implants in comparison with turned titanium surfaces of similar shapes. ${ }^{42}$

\section{Conclusion}

Surface topography of dental implants and osseointegration go hand in hand in terms of the short-term or long-term success of implants. Surface roughness plays an important part in the quality as well as the rate of osseointegration of titanium dental implants. Highly roughened implants (TPS/grit blasted) have been shown to favor mechanical anchorage and primary fixation to bone. Topographies in the nanometer range have been used to promote protein adsorption, osteoblastic cell adhesion, and the rate of bone tissue healing in the peri-implant region. Hence, the knowledge of surface topography is essential for the selection and placement of dental implants.

Conflict of Interest

None declared.

\section{References}

1 Cooper LF. Biologic determinants of bone formation for osseointegration: clues for future clinical improvements. J Prosthet Dent 1998;80(04):439-449

2 Nanci A, Wuest JD, Peru L, et al. Chemical modification of titanium surfaces for covalent attachment of biological molecules. J Biomed Mater Res 1998;40(02):324-335

3 Boyan BD, Schwartz Z, Hambleton JC. Response of bone and cartilage cells to biomaterials in vivo and in vitro. J Oral Implantol 1993;19(02):116-122
4 Schwartz Z, Swain LD, Marshall T, et al. Modulation of matrix vesicle enzyme activity and phosphatidylserine content by ceramic implant materials during endosteal bone healing. Calcif Tissue Int 1992;51(06):429-437

5 Stanford CM, Johnson GK, Fakhry A, Gratton D, Mellonig JT, Wanger $W$. Outcomes of a fluoride modified implant one year after loading in the posterior-maxilla when placed with the osteotome surgical technique. Appl Osseointegr Res 2006; 5:50-55

6 Le Guéhennec L, Soueidan A, Layrolle P, Amouriq Y. Surface treatments of titanium dental implants for rapid osseointegration. Dent Mater 2007;23(07):844-854

7 Masuda T, Salvi GE, Offenbacher S, Felton DA, Cooper LF. Cell and matrix reactions at titanium implants in surgically prepared rat tibiae. Int J Oral Maxillofac Implants 1997;12(04):472-485

8 Meyer U, Joos U, Mythili J, et al. Ultrastructural characterization of the implant/bone interface of immediately loaded dental implants. Biomaterials 2004;25(10):1959-1967

9 Berglundh T, Abrahamsson I, Lang NP, Lindhe J. De novo alveolar bone formation adjacent to endosseous implants. Clin Oral Implants Res 2003;14(03):251-262

10 Albrektsson T, Brånemark PI, Hansson HA, Lindström J. Osseointegrated titanium implants. Requirements for ensuring a longlasting, direct bone-to-implant anchorage in man. Acta Orthop Scand 1981;52(02):155-170

11 Becker W, Becker BE, Ricci A, et al. A prospective multicenter clinical trial comparing one- and two-stage titanium screwshaped fixtures with one-stage plasma-sprayed solid-screw fixtures. Clin Implant Dent Relat Res 2000;2(03):159-165

12 Wennerberg A, Albrektsson T, Andersson B, Krol JJ. A histomorphometric and removal torque study of screw-shaped titanium implants with three different surface topographies. Clin Oral Implants Res 1995;6(01):24-30

13 Wennerberg A, Hallgren C, Johansson C, Danelli S. A histomorphometric evaluation of screw-shaped implants each prepared with two surface roughnesses. Clin Oral Implants Res 1998;9(01): 11-19

14 Buser D, Schenk RK, Steinemann S, Fiorellini JP, Fox CH, Stich H. Influence of surface characteristics on bone integration of titanium implants. A histomorphometric study in miniature pigs. J Biomed Mater Res 1991;25(07):889-902

15 Gotfredsen K, Wennerberg A, Johansson C, Skovgaard LT, Hjørting-Hansen E. Anchorage of $\mathrm{TiO}_{2}$-blasted, HA-coated, and machined implants: an experimental study with rabbits. J Biomed Mater Res 1995;29(10):1223-1231

16 Hansson S, Norton M. The relation between surface roughness and interfacial shear strength for bone-anchored implants. A mathematical model. J Biomech 1999;32(08):829-836

17 Testori T, Wiseman L, Woolfe S, Porter SS. A prospective multicenter clinical study of the Osseotite implant: four-year interim report. Int J Oral Maxillofac Implants 2001;16(02):193-200

18 Conner KA, Sabatini R, Mealey BL, Takacs VJ, Mills MP, Cochran DL. Guided bone regeneration around titanium plasma-sprayed, acid-etched, and hydroxyapatite-coated implants in the canine model. J Periodontol 2003;74(05):658-668

19 Cochran DL, Schenk RK, Lussi A, Higginbottom FL, Buser D. Bone response to unloaded and loaded titanium implants with a sandblasted and acid-etched surface: a histometric study in the canine mandible. J Biomed Mater Res 1998;40(01):1-11

20 Esposito M, Coulthard P, Thomsen P, Worthington HV. Interventions for replacing missing teeth: different types of dental implants. Cochrane Database Syst Rev 2005;(01):CD003815

21 Brett PM, Harle J, Salih V, et al. Roughness response genes in osteoblasts. Bone 2004;35(01):124-133

22 Urban RM, Jacobs JJ, Tomlinson MJ, Gavrilovic J, Black J, Peoc'h M. Dissemination of wear particles to the liver, spleen, and abdominal lymph nodes of patients with hip or knee replacement. J Bone Joint Surg Am 2000;82(04):457-476 
23 Browne M, Gregson PJ. Effect of mechanical surface pretreatment on metal ion release. Biomaterials 2000;21(04):385-392

24 Aparicio C, Gil FJ, Fonseca C, Barbosa M, Planell JA. Corrosion behaviour of commercially pure titanium shot blasted with different materials and sizes of shot particles for dental implant applications. Biomaterials 2003;24(02):263-273

25 Ivanoff CJ, Hallgren C, Widmark G, Sennerby L, Wennerberg A. Histologic evaluation of the bone integration of $\mathrm{TiO}(2)$ blasted and turned titanium microimplants in humans. Clin Oral Implants Res 2001;12(02):128-134

26 Novaes AB Jr, Souza SL, de Oliveira PT, Souza AM. Histomorphometric analysis of the bone-implant contact obtained with 4 different implant surface treatments placed side by side in the dog mandible. Int J Oral Maxillofac Implants 2002;17(03):377-383

27 Piattelli M, Scarano A, Paolantonio M, Iezzi G, Petrone G, Piattelli A. Bone response to machined and resorbable blast material titanium implants: an experimental study in rabbits. J Oral Implantol 2002;28(01):2-8

28 Müeller WD, Gross U, Fritz T, et al. Evaluation of the interface between bone and titanium surfaces being blasted by aluminium oxide or bioceramic particles. Clin Oral Implants Res 2003;14(03): 349-356

29 Massaro C, Rotolo P, De Riccardis F, et al. Comparative investigation of the surface properties of commercial titanium dental implants. Part I: chemical composition. J Mater Sci Mater Med 2002;13(06):535-548

30 Zinger O, Anselme K, Denzer A, et al. Time-dependent morphology and adhesion of osteoblastic cells on titanium model surfaces featuring scale-resolved topography. Biomaterials 2004;25(14): 2695-2711

31 Park JY, Davies JE. Red blood cell and platelet interactions with titanium implant surfaces. Clin Oral Implants Res 2000;11(06): 530-539

32 Ellingsen JE. Pre-treatment of titanium implants with fluoride improves their retention in bone. J Mater Sci Mater Med 1995;6 (12):749-753

33 Ellingsen JE, Johansson CB, Wennerberg A, Holmén A. Improved retention and bone-tolmplant contact with fluoride-modified titanium implants. Int J Oral Maxillofac Implants 2004;19(05): 659-666

34 Davies JE. Mechanisms of endosseous integration. Int J Prosthodont 1998;11(05):391-401

35 Trisi P, Lazzara R, Rao W, Rebaudi A. Bone-implant contact and bone quality: evaluation of expected and actual bone contact on machined and osseotite implant surfaces. Int J Periodontics Restorative Dent 2002;22(06):535-545

36 Novaes AB Jr, Papalexiou V, Grisi MF, Souza SS, Taba M Jr, Kajiwara $\mathrm{JK}$. Influence of implant microstructure on the osseointegration of immediate implants placed in periodontally infected sites. A histomorphometric study in dogs. Clin Oral Implants Res 2004; 15(01):34-43

37 Papalexiou V, Novaes AB Jr, Grisi MF, Souza SS, Taba M Jr, Kajiwara JK. Influence of implant microstructure on the dynamics of bone healing around immediate implants placed into periodontally infected sites. A confocal laser scanning microscopic study. Clin Oral Implants Res 2004;15(01):44-53

38 Yokoyama K, Ichikawa T, Murakami H, Miyamoto Y, Asaoka K. Fracture mechanisms of retrieved titanium screw thread in dental implant. Biomaterials 2002;23(12):2459-2465

39 Sul YT, Johansson CB, Röser K, Albrektsson T. Qualitative and quantitative observations of bone tissue reactions to anodised implants. Biomaterials 2002;23(08):1809-1817

40 Sul YT, Johansson CB, Jeong Y, Wennerberg A, Albrektsson T. Resonance frequency and removal torque analysis of implants with turned and anodized surface oxides. Clin Oral Implants Res 2002;13(03):252-259

41 Rocci A, Martignoni M, Gottlow J. Immediate loading of Brånemark System TiUnite and machined-surface implants in the posterior mandible: a randomized open-ended clinical trial. Clin Implant Dent Relat Res 2003;5(Suppl 1):57-63

42 Jungner $M$, Lundqvist $P$, Lundgren $S$. Oxidized titanium implants (Nobel Biocare TiUnite) compared with turned titanium implants (Nobel Biocare mark III) with respect to implant failure in a group of consecutive patients treated with early functional loading and two-stage protocol. Clin Oral Implants Res 2005;16 (03):308-312 